\title{
Resistance to Fusarium oxysporum f. sp. melonis Race 1,2 in Muskmelon Lines Nad-1 and Nad-2
}

\author{
N. Ficcadenti, S. Sestili, S. Annibali, and G. Campanelli, Research Institute for Vegetable Crops, Via Salaria 1, \\ 63030, Monsampolo del Tronto, Ascoli Piceno, Italy; and A. Belisario, M. Maccaroni, and L. Corazza, Plant Pa- \\ thology Research Institute, Via C. G. Bertero 22, 00156, Rome, Italy.
}

\begin{abstract}
Ficcadenti, N., Sestili, S., Annibali, S., Campanelli, G., Belisario, A., Maccaroni, M., and Corazza, L. Resistance to Fusarium oxysporum f. sp. melonis race 1,2 in muskmelon lines Nad1 and Nad-2. Plant Dis. 86:897-900.

Of seven doubled-haploid melon lines parthenogenetically originated using irradiated pollen, two lines, Nad-1 and Nad-2, were selected for resistance to Fusarium wilt after successive inoculations with $F$. oxysporum f. sp. melonis race 1,2w virulent isolate. Nad-1 and Nad-2 were compared with the commercial hybrids and with the parent cvs. Isabelle and Giallo di Paceco. Evaluation of germplasm extended over a 2-year period showed a higher resistance of Nad-1 and Nad-2 plants to Fusarium oxysporum f. sp. melonis race 1,2 than other genotypes tested in this study. The resistance expressed in the two doubled-haploid lines could be due to their homozygous state that maximizes the expression of the genes for resistance already present in the parental line Isabelle. The use of this source of resistance may be exploited commercially either in rootstocks or to facilitate breeding for F1 hybrids. Future research will concentrate on the identification of genetic markers associated with resistance to race 1,2 using these doubledhaploid lines.
\end{abstract}

Additional keywords: breeding, doubled-haploid, Fusarium wilt, resistance

Fusarium wilt of muskmelon (Cucumis melo L.), caused by Fusarium oxysporum Schlechtend.:Fr. f. sp. melonis (Leach \& Currence) W.C. Snyder \& H.N. Hans., is a severe disease worldwide. It occurs throughout Italy $(3,4,7)$ and Europe $(10)$ as well as North and Central America (31), Asia $(1,8,16)$, and Africa (19). Epidemics of Fusarium wilt can be devastating with losses as much as $100 \%$ (26). Once introduced into a field, $F$. oxysporum f. sp. melonis can persist even after rotation to crops that are nonhost plants to this fungus $(2,12)$ because the fungus survives in the soil as chlamydospores, and is capable of colonizing crop residues and roots of most crops grown in rotation with melon $(2,11,12,31)$. As a result of persistence of the pathogen in soil, Fusarium wilt of muskmelon is best controlled with the use of resistant cultivars or hybrids (31). Risser et al. (18) designated race 0 , race 1 , race 2 , and race 1,2 of $F$. oxysporum f. sp. melonis based on the host resistance genes overcome by variants of the pathogen. Race 1,2 was further subdivided into race $1,2 \mathrm{y}$, which causes symptoms of yellowing, and

Corresponding author: Nadia Ficcadenti E- mail: nadiaf@insinet.it

Accepted for publication 22 April 2002.

Publication no. D-2002-0614-01R

(C) 2002 The American Phytopathological Society race $1,2 \mathrm{w}$, which causes wilt symptoms. Race 0 incites disease on muskmelon genotypes that lack genes for resistance to $F$. oxysporum f. sp. melonis. Fom-1 and Fom2 are independently inherited dominant genes in muskmelon that control resistance to races 0 and 2 , and races 0 and 1 , respectively $(18,29,30)$. The presence of both genes in a plant confers a high level of resistance to races 0,1 , and $2(15,18)$. No genes have been identified in muskmelon that confer high levels of resistance to either race $1,2 \mathrm{y}$ or race $1,2 \mathrm{w}(26,30)$. However, polygenic recessive genes have been found to confer resistance to race 1,2 in Piboule genotypes $(15,18)$. Seven doubled-haploid melon lines have been developed from parthenogenesis of irradiated pollen $(9,20)$. Crosses were performed at ISPORT (Research Institute for Vegetable Crops Section of Ascoli Piceno) between the muskmelon cv. Isabelle (INRA, Station de Génétique et d'Amélioration des fruits et Légumes, Montfavet-France), as the female parent, and the Italian landrace Giallo di Paceco, as the male parent. Two lines resulting from these crosses, Nad-1 and $\mathrm{Nad}-2$, were selected for potential sources of resistance to Fusarium wilt after repeated artificial inoculations with $F$. oxysporum $\mathrm{f}$. sp. melonis race $1,2 \mathrm{w}$ virulent isolate (unpublished data).

The objective of this study was to compare these two homozygous lines, Nad-1 and Nad-2, with commercial muskmelon genotypes that are either susceptible or resistant to race 1,2 of $F$. oxysporum $\mathrm{f}$. sp. melonis to identify potential sources of resistance to Fusarium wilt of muskmelon.

\section{MATERIAL AND METHODS}

Plant material. The muskmelon lines Nad-1 and Nad-2 were compared with the commercial muskmelon hybrids Dinero (Syngenta Seeds, Milano, Italy) and ASR04993033 (Asgrow Seeds, Latina, Italy), which are resistant to race 1,2 , and with the hybrid Quasar (Asgrow Seeds, Italy), which is susceptible to race 1,2 of $F$. oxysporum f. sp. melonis. Isabelle and Giallo di Paceco, the parents of Nad-1 and Nad-2, were included in the evaluation. The commercial hybrids served as standards by which to compare the reactions of the two doubled-haploid lines. Evaluation of germplasm for resistance extended over a 2-year period in 1999 and 2000. In 1999, all the genotypes listed above were evaluated. In 2000, lines Nad-1 and Nad-2 were compared with the parent cvs. Isabelle and Giallo di Paceco and with the commercial hybrid Dinero.

Source of inoculum. In 1997, a field isolate of $F$. oxysporum obtained from a wilted muskmelon plant in Pescia Romana (Viterbo, Italy) was cultured on potato dextrose agar (PDA), single-spored, and inoculated on the following differential varieties of muskmelon: Charentais $\mathrm{T}$ which lacks any genes for resistance, Charentais Fom-1 which is resistant to race 0 and race 2, Charentais Fom-2 which is resistant to race 0 and race 1 , and Margot which carries both the resistance genes Fom-1 and Fom-2. These inoculations were performed to establish pathogenicity of the fungal isolate and to identify the forma specialis as melonis. Differential varieties were inoculated by root-dipping in a suspension of $1 \times 10^{6}$ conidia per $\mathrm{ml}$ in sterile distilled water, following the method described by Zink (28) and Latin and Snell (14). Based on the reaction of the inoculated differentials and according to the nomenclature proposed by Risser et al. (18), the isolate was classified as $F$. oxysporum $\mathrm{f}$. sp. melonis race $1,2 \mathrm{w}$, and was numbered isolate 1018 of the ISPaVe (Istituto Sperimentale per la Patologia Vegetale, Rome, Italy) culture collection. The virulence of the isolate was considered very high (31) because it induced the first symptoms in approximately 3 days, and in 7 days it killed all the inoculated differentials (4). 
Plant inoculations. Colonies of $F$. oxysporum f. sp. melonis ISPaVe 1018 were maintained on PDA in slant cultures at $4 \pm$ $2{ }^{\circ} \mathrm{C}$ to obtain new working cultures. For long-term storage, the isolate was stored as filter paper culture (31). Fourteen-day-old cultures of $F$. oxysporum f. sp. melonis ISPaVe 1018 grown at room temperature (20 to $25^{\circ} \mathrm{C}$ ) were flooded with sterile distilled water and scraped with a sterile glass rod to obtain a purple-pink spore suspension. This slurry was filtered through two layers of sterile cheesecloth, and the filtrate was diluted with distilled water to obtain a concentration of $1 \times 10^{6}$ spores (a mixture of macroconidia and microconidia) per ml. Seeds of plants to be assayed for resistance to Fusarium wilt were surface-disinfected with $1 \% \mathrm{NaOCl}$ for $20 \mathrm{~min}$, rinsed in sterile distilled water, and planted in cell-type plastic growing trays (Bamaplast, Pistoia, Italy), one seed per 10-cm-diameter cell, filled with an autoclaved potting mix of peat and sand (1:1, vol/vol).

In 1999, to study the response of the different genotypes to inoculation with $F$. oxysporum f. sp. melonis at different plant ages, seedlings were inoculated at the second-true-leaf stage ( 21 days old), and the third-true-leaf stage (28 days old). In 2000, seedlings were inoculated at the cotyledon to first-true-leaf stage only (10 days old), because this maturity is reported to be the most susceptible to Fusarium wilt $(14,28,29)$. When plants were at the appropriate growth stage for inoculation they were removed from the seedling trays, the roots were washed in tap water, pruned at a length of approximately $2.5 \mathrm{~cm}$, and dipped for $1 \mathrm{~min}$ in the spore suspension (28). All seedlings per each assay and replication were dipped in the spore suspension at the same time, and the spore suspension was changed for successive inoculations. The inoculated seedlings

Table 1. Analysis of variance (ANOVA) of the experiments performed in 1999

\begin{tabular}{lrcc}
\hline Source & DF & Mean square & $\boldsymbol{F}$ value $^{\mathbf{z}}$ \\
\hline Replications & 2 & 1.16 & 0.017 \\
Muskmelon genotypes (A) & 6 & 6848.84 & $102.51^{* *}$ \\
Error & 12 & 66.81 & $120.84^{* *}$ \\
Plants maturity (B) & 1 & 5663.13 & $20.10^{* *}$ \\
A $\times$ B & 6 & 942.17 & \\
Error & 14 & 46.86 & \\
Total & 41 & &
\end{tabular}

Table 2. Analysis of variance (ANOVA) of the experiment performed in 2000

\begin{tabular}{lccc}
\hline Source & DF & Mean square & $\boldsymbol{F}$ value \\
\hline Replications & 2 & 5.57 & 0.13 \\
Muskmelon genotypes & 4 & 3876.57 & $93.34^{* *}$ \\
Error & 8 & 41.53 & \\
Total & 14 & & \\
\hline
\end{tabular}

${ }^{\mathrm{z}}$ Values followed by $* *$ are statistically significant at $P<0.01$.

Table 3. Percentage of muskmelon plants remaining free of wilt symptoms 21 days after inoculation with Fusarium oxysporum f. sp. melonis race 1,2 at different stages of seedling maturity in 1999

\begin{tabular}{|c|c|c|c|c|}
\hline \multirow[b]{3}{*}{ Muskmelon genotype } & \multirow[b]{3}{*}{ Disease reaction $^{t}$} & \multicolumn{3}{|c|}{ Healthy plants (\%) } \\
\hline & & \multicolumn{2}{|c|}{$\begin{array}{l}\text { Seedling growth stage at the } \\
\text { time of inoculations }\end{array}$} & \multirow[b]{2}{*}{ Mean genotype } \\
\hline & & $\begin{array}{l}\text { Second-true- } \\
\text { leaf }^{u}\end{array}$ & $\begin{array}{l}\text { Third-true- } \\
\text { leaf }^{\mathrm{v}}\end{array}$ & \\
\hline Isabelle $^{\mathrm{w}}$ & $\mathrm{R}$ & $100.0 \mathrm{a}^{\mathrm{x}, \mathrm{y}}$ & $16.7 \mathrm{f}$ & $58.3 \mathrm{~b}$ \\
\hline $\mathrm{Nad}-2$ & $\mathrm{R}$ & $100.0 \mathrm{a}$ & $83.3 \mathrm{~cd}$ & $91.7 \mathrm{a}$ \\
\hline Dinero & $\mathrm{R}$ & $100.0 \mathrm{a}$ & $53.3 \mathrm{e}$ & $76.7 \mathrm{a}$ \\
\hline Nad-1 & $\mathrm{R}$ & $93.3 \mathrm{bc}$ & $80.0 \mathrm{~d}$ & $86.7 \mathrm{a}$ \\
\hline ASR04993033 & $\mathrm{R}$ & $96.7 \mathrm{ab}$ & $76.7 \mathrm{~d}$ & $86.7 \mathrm{a}$ \\
\hline Giallo di Paceco $\mathrm{z}$ & $\mathrm{S}$ & $0.0 \mathrm{~g}$ & $3.3 \mathrm{~g}$ & $1.7 \mathrm{c}$ \\
\hline Quasar & $\mathrm{S}$ & $0.0 \mathrm{~g}$ & $0.0 \mathrm{~g}$ & $0.0 \mathrm{c}$ \\
\hline Mean treatment & & $70.0 \mathrm{a}$ & $44.8 \mathrm{~b}$ & \\
\hline
\end{tabular}

${ }^{\mathrm{s}}$ Seedlings were inoculated by root-dipping in a suspension of $1 \times 10^{6}$ conidia per $\mathrm{ml}$.

${ }^{\mathrm{t}}$ Disease reaction to $F$. oxysporum $\mathrm{f}$. sp. melonis race $1,2 \mathrm{w}$ : $\mathrm{R}=$ resistant, $\mathrm{S}=$ susceptible.

u Twenty-one-day-old plants.

$\checkmark$ Twenty-eight-day-old plants.

${ }^{\mathrm{w}}$ Female parent.

${ }^{\mathrm{x}}$ Each value is the mean on ten plants in each of three replications.

${ }^{y}$ Means followed by the same letter are not significantly different at $P=0.05$ using the least significant difference $t$ tests.

${ }^{\mathrm{z}}$ Male parent. were transplanted in plastic growing trays (one plant per cell), filled with a steamed potting mix (1 part each of soil, sand, and peat), and placed in a greenhouse at $20 / 28^{\circ} \mathrm{C}$, night/day temperatures. The roots of control plants were pruned to a length of approximately $2.5 \mathrm{~cm}$ and dipped in tap water prior to transplanting $(14,28,30,31)$.

Evaluation for resistance to Fusarium wilt. Three replications were used per genotype and seedling growth stage, each replication consisting of 10 plants in 1999, and 20 plants in 2000. The experimental design was randomized complete blocks. Inoculated seedlings were examined at 2- to 3-day intervals. The number of dead and healthy plants was recorded 21 days after inoculation $(3,4,16)$. Plants were rated as susceptible to Fusarium wilt if they died, or resistant to Fusarium wilt if they remained free of wilt symptoms $(29,30)$. In both years, reisolations were performed 21 days after inoculation. Sections of stem of one-third of the surviving plants were collected, surface-disinfected, and pieces of xylem were cut and plated on PDA to verify infection by $F$. $o x$ ysporum $(4,16)$.

Data analysis. The percentage of plants free of wilt symptoms was recorded. All data were subjected to arcsine transformation to normalize their distribution. For each experiment, analysis of variance (ANOVA) was used to evaluate the significance of differences in susceptibility among the genotypes. For the experiment performed in 1999, the randomized complete factorial design of two factors, genotypes and plant maturity, was used. The two-way ANOVA was carried out for the experiment conducted in 2000. Differences among genotype mean were determined using least significant differences $(P=$ $0.05)$. Statistical computations were performed with MSTAT-C (Michigan State University, East Lansing).

\section{RESULTS}

Symptoms were observed on susceptible plants as early as 3 to 5 days after inoculation, and seedlings of susceptible genotypes were usually killed within 7 to 15 days. All plants were free of wilt symptoms in the control treatments.

ANOVA indicated that in both years the percentage of healthy plants remaining after inoculations was influenced by the genotype, as shown in Table 1 and Table 2. The age of the seedlings at the time of inoculations and the interaction genotype $x$ plant maturity was also statistically significant at $P<0.01$ in the experiments performed in 1999 (Table 1).

Results of the inoculations performed in 1999 and 2000 are shown in Table 3 and Table 4. For all the experiments, ratings for incidence of Fusarium wilt were made 21 days after inoculation. For the susceptible genotypes such as Giallo di Paceco and Quasar in 1999, and Giallo di Paceco in 
2000, wilt symptoms appeared earlier and were more severe regardless of the plant age at the time of inoculation. The susceptible cv. Giallo di Paceco and the hybrid Quasar consistently ranked low (highly susceptible) among the genotypes tested, with very few or no seedlings remaining healthy 21 days after inoculation (Tables 3 and 4). In 1999, significant differences were observed in incidence of Fusarium wilt among resistant genotypes depending on the plant age at the time of inoculation. Mean treatments pointed out that the percentage of plants remaining free of wilt symptoms was statistically superior at the second-true-leaf stage than the third-trueleaf stage with the value of 70.0 and 44.8 , respectively (Table 3 ). In particular, at the third-true-leaf-stage for the cv. Isabelle and the hybrid Dinero, data recorded a higher reduction in percentage of healthy plants than the two doubled-haploid lines and the hybrid ASR04993033. All data indicated that the influence of the genotype played a key role on disease development. In fact, the mean genotype reported in Table 3 showed the significant high level of resistance of the two homozygous lines Nad-1 and Nad-2 not significantly different from Dinero, but statistically superior from Isabelle. The experiment performed in 2000 confirmed the low incidence of Fusarium wilt for Nad-1 and Nad-2, which was statistically similar to the incidence of Fusarium wilt for the commercial hybrid Dinero, but significantly less than the disease incidence for the cv. Isabelle (Table 4).

Typical cultures of $F$. oxysporum were reisolated from inoculated but healthy plants of Dinero, Nad-1 and Nad-2, and from three healthy plants of Isabelle and ASR04993033, 21 days after inoculation at the second-true-leaf stage, in 1999. In the same year, the number of healthy plants at the third-true-leaf stage from which $F$. oxysporum was reisolated remained the

Table 4. Percentage of muskmelon plants remaining free of Fusarium wilt symptoms 21 days after inoculation with Fusarium oxysporum $\mathrm{f}$. sp. melonis race $1,2 \mathrm{w}$ at the cotyledon to the first-true-leaf stage ${ }^{u}$ in 2000

\begin{tabular}{|c|c|c|}
\hline $\begin{array}{l}\text { Muskmelon geno- } \\
\text { type }\end{array}$ & $\begin{array}{c}\text { Disease } \\
\text { reaction }^{v}\end{array}$ & $\begin{array}{c}\text { Healthy } \\
\text { plants }(\%)\end{array}$ \\
\hline Dinero & $\mathrm{R}$ & $96.7 \mathrm{a}^{\mathrm{w}, \mathrm{x}}$ \\
\hline Isabelle ${ }^{\mathrm{y}}$ & $\mathrm{R}$ & $83.3 \mathrm{~b}$ \\
\hline Giallo di Pacecoz & $\mathrm{S}$ & $0.0 \mathrm{c}$ \\
\hline Nad-2 & $\mathrm{R}$ & $96.7 \mathrm{a}$ \\
\hline Nad-1 & $\mathrm{R}$ & $98.3 \mathrm{a}$ \\
\hline
\end{tabular}

u Ten-day-old plants.

${ }^{v}$ Disease reaction to $F$. oxysporum f. sp. melonis race $1,2 \mathrm{w}$ : $\mathrm{R}=$ resistant, $\mathrm{S}=$ susceptible.

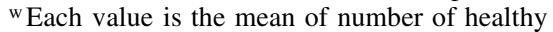
seedlings in three replications each of 20 plants.

${ }^{x}$ Means followed by the same letter are not significantly different at $P=0.05$ using the least significant difference $t$ tests.

y Female parent.

${ }^{\mathrm{z}}$ Male parent. same for Dinero, Nad-1 and Nad-2, and Isabelle, while $F$. oxysporum was obtained from four plants of ASR04993033 and from all the plants of Giallo di Paceco. In $2000, F$. oxysporum was reisolated from one healthy plant of Dinero and Isabelle, while reisolation from Nad-1 and Nad-2 gave no $F$. oxysporum culture. Pathogenicity was verified using one isolate of $F$. oxysporum obtained from each genotype, in each experiment and per each growth stage trial, confirming identification of the pathogen as $F$. oxysporum f. sp. melonis race 1,2 .

\section{DISCUSSION}

Race 1,2 of F. oxysporum f. sp. melonis has spread through Europe in the past few years $(3,4,10,23)$. In Italy, race 1,2 was predominant not only in areas of intensive melon production but also in southern regions were ecotypes of $C$. melo var. inodorus with no resistance to $F$. oxysporum f. sp. melonis are still cultivated $(3,4)$. The spread of this race has become a problem for melon cultivation, and the employment of genotypes with resistance to multiple races of the pathogen represents the major objective in melon breeding programs. Until recently, only a few genotypes tolerant to race 1,2 have been available commercially. These hybrids are mainly used as rootstocks (22). Therefore, the doubledhaploid lines, Nad-1 and Nad-2, which showed a more resistant response to $F$. oxysporum $\mathrm{f}$. sp. melonis race $1,2 \mathrm{w}$ than most other genotypes evaluated in this study, represent a potentially valuable source of resistance that can be exploited commercially either as rootstocks or to facilitate breeding for F1 hybrids. The origin of the resistance in these doubledhaploid lines, which was greater than the resistance observed in the mother cv. Isabelle, may have developed from the homozygous status of resistance genes in Nad-1 and Nad-2, which allows full expression of the polygenic recessive resistance to race 1,2 (15) that is present within Isabelle. Polygenic resistance is based on minor genes, which may confer a higher level of resistance when all the genes are present together in a homozygous state $(6,15)$. The use of the homozygous lines, such as Nad-1 and Nad2 , as breeding material in the genetic improvement can be extremely useful because it allows to hasten the selection of cultivars with resistance to the pathogen. Therefore, the employment of the genotypes in homozygous genetic background represents an effective strategy for maximizing resistance already present within the genotype (5). Moreover, the use of the doubled-haploid line could assist in elucidating the mode of inheritance of the resistance as reported in a recent study involving field assessment of resistance to Fusarium wilt in Linum usitatissimum L. (21).

The isolate of $F$. oxysporum f. sp. melonis used in this study (ISPaVe 1018), was considered highly virulent because it caused death of differential host plants within 7 days from inoculation at the firsttrue-leaf stage (4). The relatively high inoculum concentration $\left(1 \times 10^{6}\right.$ conidia per $\mathrm{ml}$ ) used may limit the ability to detect lower levels of resistance (29). Moreover, plants were scored as resistant to Fusarium wilt when more than $80 \%$ of the inoculated seedlings did not develop (28) wilt symptoms, even though $F$. oxysporum f. sp. melonis was isolated from healthy plants (28). The genetic improvement of muskmelon for resistance to Fusarium wilt could benefit from the use of molecular marker technology to increase selection efficiency (17). The employment of random amplified polymorphic DNA, clearest amplified polymorphic sequences, and amplified fragment length polymorphism has enabled identification of DNA fragments linked to the resistance gene Fom-2 (24-27). However, efforts are still in progress to identify molecular markers associated with the resistance gene Fom-1 (13). Future research by the authors will focus on identification of genetic markers linked to genes for resistance to race 1,2 using the doubled-haploid lines Nad-1 and Nad-2.

\section{ACKNOWLEDGMENTS}

This work was supported by the National Project of Horticulture financed by the Italian Ministry of Agriculture and Forestry.

\section{LITERATURE CITED}

1. Abou-Jawdah, Y., and Al-Khoury, A. M 1996. First report of the identification of race 0 , 1, and 1,2 of Fusarium oxysporum f. sp. melonis in Lebanon. Plant Dis. 80:711.

2. Banihashemi, Z., and DeZeeuw, D. J. 1975. The behavior of Fusarium oxysporum f. sp. melonis in the presence and absence of host plants. Phytopathology 65:1212-1217.

3. Belisario, A., Luongo, L., and Corazza, L. 1999. La tracheofusariosi, una preoccupante avversità del melone d'inverno. Tec. Agric. 23:41-44.

4. Belisario, A., Luongo, L., Corazza, L., and Gordon, T. R. 2000. Indagini su popolazioni di Fusarium oxysporum f. sp. melonis in Italia. Colture Protette 3:87-89.

5. Bruton, B. D. 1998. Soilborne disease in cucurbitaceae: pathogen virulence and host resistance. Cucurbitaceae'98 143-166.

6. Clerjeau, M., Laterrot, H., Lecoq, H., and Pitrat, M. 1981. Orentations actuelles de la sélection de varétés résistantes aux maldies chez les plantes maraîchères. Agronomie 1:41-48.

7. Corazza, L. 1998. Le fusariosi del melone d'inverno. Colture Protette 5:39-41.

8. Erzurum, K., Taner, Y., Secer, E., Yanmaz, R., and Maden, S. 1999. Occurrence of races of Fusarium oxysporum f. sp. melonis causing wilt on melon in Central Anatolia. J. Turkish Phytopathol. 28:87-97.

9. Ficcadenti, N., Veronese, P., Sestili, S., Crinò, P., Lucretti, S., Schiavi, M., and Saccardo, F. 1995. Influence of genotype on the induction of haploidy in Cucumis melo L. by using irradiated pollen. J. Genet. Breed. 49:359-364.

10. Gomez Vazquez, J., and Tello Marquina, J. C. 2000. Presenzia de la razza 1,2 de Fusarium oxysporum f. sp. melonis en Almeria. Bol. San. Veg. Plagas 26:27-33.

11. Gordon, T. R., Okamoto, D. 1990. Colonization of crop residue by Fusarium oxysporum f. sp. melonis and other species of Fusarium. 
Phytopathology 80:381- 386.

12. Gordon, T. R., Okamoto, D., and Jacobson, D. J. 1989. Colonization of muskmelon and nonsusceptible crops by Fusarium oxysporum $\mathrm{f}$. sp. melonis and other species of Fusarium. Phytopathology 79:1095-1100.

13. Katzir, N., and Paris, H. S. 2000. Towards the development of molecular markers linked to race 2 Fusarium wilt resistance in melon $(\mathrm{Cu}$ cumis melo L.). Acta Hortic. 510:415-419.

14. Latin, R. X., and Snell, S. J. 1986. Comparison of methods for inoculation of muskmelon with Fusarium oxysporum f. sp. melonis. Plant Dis. 70:297-300.

15. Messiaen, C. M., Risser, G., and Pecaut, P. 1962. Etude des plantes resistantes au Fusarium oxysporum $\mathrm{f}$. sp. melonis dans la variété de melon Cantaloup Charentais. Ann. Amélior. Plant. 12:157-164.

16. Namiki, F., Shiomi, T., Nishi, K., Kayamura, T., and Tsuge, T. 1998. Pathogenicity and genetic variation in the Japanese strains of Fusarium oxysporum f. sp. melonis. Phytopathology 88:804-810.

17. Pitrat, M. 1991. Linkage groups in Cucumis melo L. J. Hered. 82:406-411.

18. Risser, G., Banihashemi, Z., and Davis, D. W. 1976. A proposed nomenclature of Fusarium oxysporum f. sp. melonis races and resistance genes in Cucumis melo. Phytopathology 66:1105-1106.

19. Schreuder, W., Lamprecht, S. C., and Holz, G. 2000. Race determination and vegetative compatibility grouping of Fusarium oxysporum f. sp. melonis from South Africa. Plant Dis. 84:231-234.

20. Sestili, S., Veronese, P., Ficcadenti, N., Crinò, P., and Saccardo, F. 1994. Induction of haploidy in muskmelon (Cucumis melo L.). (Abstr.) Proc. VIII Int. Congr. Plant Tissue Cell Culture 88:S3-29.

21. Spielmeyer, W., Lagudah, E. S., Mendham, N., and Green, A. G. 1998. Inheritance of resistance to flax wilt (Fusarium oxysporum f.sp.lini Schlecht) in a doubled haploid population of Linum usitatissimum L. Euphytica 101:287-291.

22. Trionfetti Nisini, P., Granati, E., Belisario, A., Luongo, L., Temperini, O., and Crinò, P. 1999. Resistenza in portinnesti di melone alla razza 1-2 di Fusarium oxysporum f. sp. melonis. L' Inf. Agr. 55:45-47

23. Veloso, M. M., Melo, E. M. P. F., Jorge-Silva, M. L., and Bravo, M. A. 2000. Genetic diversity in Fusarium oxysporum f. sp. melonis. EPPO Bull. 30:195-197.

24. Wang, Y. H., Thomas, C. E., and Dean, R. A. 1997. A genetic map of melon (Cucumis melo L.) based on amplified fragment length polymorphism (AFLP) markers. Theor. Appl. Genet. 95:791-798.

25. Wechter, W. P., Thomas, C. E., and Dean, R. A. 1998. Development of sequence specific primers which amplify a $1.5 \mathrm{~kb}$ DNA marker for race 1 Fusarium wilt resistance in $\mathrm{Cucu}$ mis melo. Hortic. Sci. 33:291-192.
26. Wechter, W. P., Whitehead, M. P., Thomas, C. E., and Dean, R. A. 1995. Identification of a randomly amplified polymorphic DNA marker linked to the Fom-2 Fusarium wilt resistance gene in muskmelon MR-1. Phytopathology 85:1245-1249.

27. Zheng, X. Y., Wolff, D. W., Baudracco-Arna, S., and Pitrat, M. 1999. Development and utility of cleaved amplified polymophic sequences (CAPS) and restriction fragment length polymorphisms (RFLPs) linked to the Fom-2 Fusarium wilt resistance gene in melon (Cucumis melo L.). Theor. Appl. Genet. 99:453-463.

28. Zink, F. W. 1983. Reaction of muskmelon germ plasm to inoculation with Fusarium ox ysporum f. sp. melonis race 2. Plant Dis. 67:1251-1255.

29. Zink, F. W. 1992. Genetics of resistance to Fusarium oxysporum f. sp. melonis races and 2 in muskmelon cultivars Honey Dew, Iroquois, and Delicious 51. Plant Dis. 76:162 166.

30. Zink, F. W., and Thomas, C. E. 1990. Genetics of resistance to Fusarium oxysporum f. sp. melonis races 0,1 , and 2 in muskmelon line MR-1. Plant Dis. 80:1230-1232.

31. Zuniga, T. L., Zitter, T. A., Gordon, T. R., Schroeder, D. T., and Okamoto, D. 1997. Characterization of pathogenic races of Fusa rium oxysporum f. sp. melonis causing Fusarium wilt of melon in New York. Plant Dis. 81:592-596. 